\title{
A PROFILE OF THE WORLD'S YOUNG DEVELOPING COUNTRY MIGRANTS
}

\author{
David J. McKenzie \\ Development Research Group, World Bank
}

\begin{abstract}
Individual level census and household survey data are used to present a rich profile of the young developing migrants around the world. Youth are found to comprise a large share of all migrants, particularly in migration to other developing countries, with the probability of migration peaking in the late teens or early twenties. The paper examines in detail the age and gender composition of migrants, whether or not young migrants move alone or with a parent or spouse, their participation in schooling and work in the destination country, the types of jobs they do, and the age of return migration. The results suggest a high degree of commonality in the youth migrant experience across a number of destination countries. In particular, developing country youth tend to work in similar occupations all around the world, and are more concentrated in these occupations than older migrants or native youth. Nevertheless, there is also considerable heterogeneity among youth migrants: 29 percent of 18 to 24 year olds are attending school in their destination country, but another 29 percent are not working or in school. This illustrates both the potential of migration for building human capital, and the fear that lack of integration prevents it from being used.
\end{abstract}

World Bank Policy Research Working Paper 4021, October 2006

The Policy Research Working Paper Series disseminates the findings of work in progress to encourage the exchange of ideas about development issues. An objective of the series is to get the findings out quickly, even if the presentations are less than fully polished. The papers carry the names of the authors and should be cited accordingly. The findings, interpretations, and conclusions expressed in this paper are entirely those of the authors. They do not necessarily represent the view of the World Bank, its Executive Directors, or the countries they represent. Policy Research Working Papers are available online at http://econ.worldbank.org. 


\section{Introduction}

Globalization has led to much faster movements of goods, technology, money, and ideas across borders, but large barriers remain to the movement of people. Despite these barriers, many people move, and by 2005 an estimated 190 million of the world's population lived outside their country of birth. ${ }^{1}$ Large income gaps coupled with diverging demographics between developed and developing countries may amplify the pressures for migration. Holzmann (2005) estimates that without further migration the labor force in Europe, Russia, and high-income East Asia and the Pacific is projected to fall by 43 million between 2005 and 2025, while it is projected to rise by 19 million in China, 77 million in Latin America, 82 million in the Middle East, North Africa and Turkey, 93 million in low and middle income East Asian and Pacific countries, 211 million in Sub-Saharan Africa and 292 million in South and Central Asia.

It has long been observed that people are more likely to migrate while young, so if more migration is to occur, it is likely to be youth doing it. Indeed, in the 1930s Dorothy Thomas concluded that perhaps the only generalization that could be made in regard to differentials in internal migration was that migrants tended to be young adults or people in their late teens (quoted in Lee, 1966). Despite this general observation, very little is known about the characteristics of young migrants. National statistical agencies typically only publish very aggregated information on the age structure of migration, seldom providing cross-tabulations of age with other characteristics of interest such as country of origin. Furthermore, aggregate statistics do not provide information on whether youth are

\footnotetext{
${ }^{1}$ Population Division of the Department of Economic and Social Affairs of the United Nations Secretariat, Trends in Total Migrant Stock: The 2005 Revision.
} 
migrating alone or with others, their participation in education and the labor market, the types of jobs they work in, and whether or not they ever return to their home countries.

All these factors are important for helping to assess the potential impact of migration on young migrants and on the development of their sending countries. This paper aims to be a first step in filling these knowledge gaps, by using microdata from national censuses and large scale household surveys in order to provide a detailed description of the lives and circumstances of young migrants from developing countries. Detailed data are available for migration to developed and developing countries, allowing comparison in South-North and South-South migration patterns.

Some of the main patterns observed are:

- Youth are a high share of the flow of migrants, especially in migration to developing countries. The share of 12 to 24 year olds in total migration is much smaller in migration to countries such as Canada, which rely on skill-intensive admission criteria.

- The share of females among youth migrants varies from 39\% in South Africa and $42 \%$ in the U.S. to $65 \%$ in Argentina, averaging 50 percent across all countries looked at.

- Youth migrating to other developing countries are less likely to be accompanying a parent migrating. About 80 percent of 12 to 14 year olds accompany a parent, compared to 50 percent of 15 to 17 year olds and less than 20 percent of 18 to 24 year olds. 
- Female youth who migrate are much more likely to be married and accompanying a spouse than male youth migrants.

- There is substantial migration for education, even to some developing countries such as South Africa and Argentina. However, at the same time, one finds 20 percent or more of 18 to 24 year olds that are neither in school nor working.

- Migrant youth tend to be more heavily concentrated in a few occupations than both older migrant workers and native youth.

- The age of return migration is also very young in many countries, with the median return migrant being aged 25 to 30. This leaves considerable time for working in the home country.

The rest of the paper is structured as follows. Section 2 outlines the theoretical reasons to expect migrants to be young. Section 3 outlines the data (which is described in detail in an Appendix). Age and gender patterns of migration are presented in Section 4. Section 5 examines whether migrants live with parents and are married, while Section 6 looks at participation in school and work. Section 7 considers the jobs young migrants work in, while Section 8 estimates age profiles of return migration. Section 9 concludes.

\section{Migration Theory and Age of Migration}

Migration theory offers reasons to expect high youth participation in migration due to individual, family, and community factors: 
Individual factors. The classic economic explanation for the greater tendency of the young to migrate is that migration is an investment, requiring individuals to incur costs to generate the returns from higher income (Sjaastad, 1962). Costs include the financial costs of moving, finding a job, and forgoing earnings and the psychic costs of leaving familiar surroundings and adapting to a new labor market. The expected returns depend on the wage, the probability of obtaining a job (Todaro, 1969), and the length of time working overseas. Young people are likely to have both higher lifetime returns and face lower costs from moving. Expected returns can be higher because they have more of their human capital in education than in job-specific skills than do older workers—and longer working lives. The forgone earnings from migrating are likely to be less for youth, especially in countries with high levels of youth unemployment and strict seniority rules that lower wages more for the young. The psychic costs of moving may also be lower, since age tends to raise investments in family and other contacts (Simon 1986, Lundborg 1991).

Family factors. A key insight of the new economics of migration literature (Stark and Bloom 1985, Stark and Levhari 1982) is that the decision to migrate is often a decision of the family, not just an individual, particularly in developing countries, where imperfect credit and insurance markets create a rationale for migrating to diversify risk and finance costly household investment activities. Households can send one of their members and count on remittances to help them cope with shocks, such as financial crises and natural disasters. ${ }^{2}$ They will select that member not just based on who has the greatest

\footnotetext{
${ }^{2}$ See, for example, Yang and Choi (2005) for evidence that Filipino households experiencing rainfall shocks receive more remittances and McKenzie (2003) for evidence showing an increase in remittances received by households during the Mexican peso crisis of 1995.
} 
individual gains from migrating — but also consider the household functions the member performs, and the likelihood of the member remitting money. In many societies parents exhibit greater control over daughters than sons, so young women may be especially likely to be sent for family reasons. Several researchers argued that this is so in the Philippines, where the majority of migrants are women. ${ }^{3}$

Community factors. Once some young people have migrated, community factors make it more likely that other youth will migrate too. One reason for this is the migrant social network, which lowers the costs and increases the benefits of migrating. Since youth are more likely to migrate due to the reasons just discussed, a young potential migrant is more likely to have a recent migrant in his or her peer network than an older individual, and so may be more likely to benefit from the migrant network. Over time a culture of migration can then develop in a community, with migration becoming a rite of passage for youth, and with those not migrating considered lazy and unenterprising (Massey et al, 1998).

\section{Data}

The main source of data for this paper is public use microdata from national censuses and large scale household surveys. Census data from 2000 or 2001 is used for five major migrant receiving countries (Canada, South Africa, Spain, the United Kingdom, and the United States). This is coupled with household survey data for two regional migrant destinations, Argentina and Côte d'Ivoire. Altogether this yields a rich dataset of individual-level observations on almost 300,000 migrants aged 12 to 24 . I supplement

\footnotetext{
${ }^{3}$ See Massey et al. (1998). Lauby and Stark (1988) argue this is also the case for rural-to-urban migration in the Philippines.
} 
this main dataset with data on return migrants from household surveys in Albania, Mexico, Pakistan, and the Philippines, and with customized cross-tabulations from the 2003 Census in Oman. Full details of the source of each country's data are provided in an Appendix. Appendix Table 1 shows the main source countries of youth migrants for each receiving country, showing significant geographic variation. Taken together these surveys allow us to construct a comprehensive picture of developing country youth migration around the world, and to cover both migration to developed and to other developing countries.

For each of the countries for which we have microdata, I try to distinguish between the stock and the flow of youth migrants. The stock is defined as all 12 to 24 years who were born abroad in a developing country and are now living in the country surveyed. Many of these individuals could have come to their current country of residence as babies or young children, in which case we would expect their migration decision to be made by parents or other family members. I therefore also consider the flow of youth migrants, defined as those 12 to 24 year olds who recently arrived in their host country, where "recently" is typically taken to be within the last two years. I consider only youth migrants from developing countries. For most of the countries studied developing country migrants comprise the bulk of all migrants. Developing country youth comprise 89 percent or more of the flow of young migrants into all countries but the United Kingdom, where the share is 50 percent. 
The data used here are the best available to look at the age patterns of migration in a comparable way across a number of countries in the world. One caveat is that youth are more likely to migrate illegally than older migrants. ${ }^{4}$ To the extent that censuses and surveys undercount illegal migrants, the share of youth amongst total migrants will be even higher than calculated here.

\section{Age and Gender Patterns of Migration}

Figure 1 then uses this microdata to plot kernel densities of the age distribution of the migrant flow in different countries around the world. This is supplemented by Table 1, which gives the share of migrants who are aged 12 to 24, and 12 to 29 in each country, and by Table 2, which gives the share of young migrants who are female.

This figure and the tables confirm that youth make up a large share of migrants around the world, but also show that there is considerable diversity in the age flow and gender patterns. The share of females among youth migrants varies from $39 \%$ in South Africa and $42 \%$ in the U.S. to $65 \%$ in Argentina. The share of 12 to 24 year olds in the migrant flow varies from only 20\% in Canada to 45\% in Côte d'Ivoire. In most cases youth are a much larger share of the flow than of the stock, suggesting that a good number of migrants stay for extended periods of time in their host countries. For comparison with the microdata, cross-tabulations from Oman show that 10 to 24 year olds comprise only 9.5 percent of the stock of male migrants, and 19.7 percent of the stock of female migrants.

\footnotetext{
${ }^{4}$ This is seen in both Mexico and Albania. See World Bank (2006).
} 
The general pattern found here is that youth are a larger share of migrants to developing countries, and a smaller share of migrants to developed countries. Developed countries like Canada which use a skill-intensive points system to select immigrants have a much smaller share of youth than countries such as the United States, where family reunification and illegal migration are more important. Likewise, within the United States, countries where migrants mostly come through skilled and education categories have lower youth shares: only 17 percent of the flow of Chinese immigrants are aged 1224, compared with youth shares of more than 40 percent from Mexico, Honduras, Guatemala, and El Salvador, for whom family migration and illegal channels are more important.

\section{Travelling alone or along?}

Given this large share of youth amongst the world's migrant population, one question which arises is whether these young migrants are migrating alone, or simply accompanying the migration decision of other family members. Even youth who migrate alone may be migrating as the result of a family decision to send one member abroad, yet such migration is still very different to a teenager accompanying a parent or a wife accompanying a husband. To explore such patterns, Table 3 reports the proportion of youth migrants who are living with a parent, while Table 4 reports the proportion who are married. This is done separately for three age ranges: 12 to 14,15 to 17 , and 18 to 24 , since one would expect the degree of autonomy to change with age. 
A large fraction of 12 to 14 year olds and many 15 to 17 year olds are accompanying or joining migrant parents. This is more common in youth migration to developed countries, which enforce more strongly age restrictions on work and which allow children under 18 to join their parents through special family reunification immigration categories. Over 90 percent of 12 to 14 year olds moving to Canada and the United Kingdom live with at least one parent, compared with less than 60 percent migrating to South Africa and less than 50 percent migrating to Côte d'Ivoire. A much smaller percentage of 18 to 24 year olds migrate or live with their parents: less than 20 percent in most countries, except Canada, which again shows how most migration to Canada is through high skilled categories which exclude youth as the principal migrants. Most youth migrants to Oman also do not live with their parents: $22.1 \%$ of $15-24$ year old males and $23.5 \%$ of $15-24$ year old females live with their parents.

The immigration systems of most countries also provide for fairly easy migration of the spouse of an existing citizen or legal resident. Young female migrants often migrate to accompany or join their migrant spouse, and young male migrants are much less likely to be married. Of 18 to 24 year old females migrating to Côte d'Ivoire 74 percent are married compared with 38 percent of males, and 45 percent of females this age migrating to the Canada are married, compared with only 12 percent of men. For Oman, crosstabulations show 19.6 percent of 15-24 year old migrant men are married, compared to 43.7 percent of 15-24 year old migrant women. 


\section{Students, Workers, or Neither?}

Youth migration can serve to build human capital if young migrants attend school in the country they move to, and also through work experience. In contrast, a key policy concern in many countries is a lack of integration of young immigrants, manifested in terms of high numbers of unemployed out-of-school youths. Tables 5, 6 and 7 investigate this in practice by examining the proportion of young migrants who attend school, work, and who do neither. Again I separate into three age groups, and by gender.

Table 5 shows that the vast majority of 12 to 14 year old migrants are attending school, except in Côte d'Ivoire, where less than 20\% of all females are. However, even among 12 to 14 year olds, $10 \%$ of males and $8 \%$ of females are not attending school in the U.S. among new migrants. Among 18 to 24 year olds, one finds over half are attending school in Canada and the United Kingdom, reflecting the importance of migration for education in these countries. However, there are also sizeable proportions of 18 to 24 year olds attending school in Argentina and South Africa, showing regional migration for higher education. In fact, a higher proportion of male 18 to 24 year old migrants to these two countries are attending school than male migrants to Spain and the United States in this age range. In Oman, $16.3 \%$ of males 15 to 24 and $20.1 \%$ of females $15-24$ are attending school.

A comparison of the school and work patterns of recent migrants to the overall stock of migrants shows that more recent migrants are less likely to be attending school, and more likely to be neither attending school nor working. Thus youth who have migrated as 
young children are more likely to be attending school than youth of the same age who have just recently migrated.

Table 6 shows male migrants tend to have a higher likelihood of working than young female migrants, with the exception of the United Kingdom and Canada, which have roughly equal proportions. This gender difference is also seen in Oman, where $75.7 \%$ of migrant males aged $15-24$ are working, compared to $45.5 \%$ of female migrants aged 15 24. Many of the surveys do not ask about work of 12 to 14 year olds. The available data shows a high incidence of child labor among youth of this age in Côte d'Ivoire, with low rates in Argentina and Spain. Many more 15 to 17 year old youths are working in some countries: $40 \%$ of males in the U.S. and $46 \%$ of males in Côte d'Ivoire, while rates are less than 20\% in Canada and Spain.

Youth who are neither working nor in school are often the cause of most concern for policymakers. Table 7 shows that the proportion of young migrants involved in neither activity is very large in some countries. As one would expect, the proportions are generally higher for young women, who may be involved in raising children or other household activities. However, the rates are still high among males: 20 percent or more of recently arrived male 18 to 24 year olds are "idle" in Argentina, South Africa, Spain and the United States. In contrast, Canada and the United Kingdom have much lower proportions of young migrants who aren't in either school or work. 


\section{What types of jobs do they work in?}

The individual level data can also be used to look at the types of jobs young migrants work in. Table 8 reports the most common 5 occupations for recently arrived female and male migrants aged 18 to 24 in each country for which data is available. The share of all recent 18 to 24 year old migrants working in this occupation is then compared to the percentage of the stock of 18 to 24 year old migrants in this occupation; the percentage of recent 30-50 year old migrants in this occupation; and the percentage of native youth in this occupation. The latter two comparisons allow one to see whether the types of jobs recent immigrant youth work in are similar to those worked in by older recent immigrants (and are thus simply "immigrant jobs") and to those worked in by native youth (and are thus "youth jobs").

Young men tend to work in physically intensive jobs like construction and agricultural labor. Young migrant women are most likely to be domestic workers, cashiers, sales clerks, waitresses and cooks. In Oman, the most common jobs for youth are also service occupations. Many of these jobs are considered to be of low status in developed countries, and offer little in the way of career advancement. Sociologists have argued that this creates a structural demand for workers who see employment as solely a means of income generation (see Massey et al. 1988 for a review). This role was traditionally filled by teenagers in developed countries, whose lower labor-force participation therefore creates additional demand for immigrant youth to fill these positions. 
Comparing the percentage of recent youth migrants working in certain occupations to the percentage of older migrants and the percentage of native youth working in these jobs shows that young migrants tend to be more clustered in certain occupations. For example, in Spain, $22 \%$ of young male migrants are agricultural laborers, compared to $14 \%$ of 30 50 year old migrants and less than 3 percent of native youth workers. Other jobs tend to be similar across immigrant age groups, but different from youth (e.g. in Argentina, 69\% of young migrant women are in domestic service, compared to $68 \%$ of $30-50$ year old migrant women, and only $20 \%$ of native young women). Yet others seem to be common for native and immigrant youth, but less common for older migrants, such as sales and cashier jobs for women.

In order to formally measure whether recent youth migrants are clustered in just a few jobs, I calculate a Herfindahl Index to measure the degree of occupational concentration. This is the sum of the squared proportions of workers in each occupation category. The index takes values between 0 and 1 , with 0 being the least concentrated and 1 indicating complete concentration, with all workers working in the same occupation. This can only be done accurately for surveys with large samples and rich occupational coding, restricting the analysis to Spain, South Africa and the U.S. Calculating this index over all 475 occupation categories listed in the 2000 U.S. Census gives a Herfindahl index for recent male youth of 0.028 , which is higher than the indices for older migrants and native youth (Table 9). We also see male migrant youth to be more concentrated in just a few jobs in Spain and South Africa. The results for females are more mixed, but in two out of 
three cases one sees higher concentration for immigrant youth than for native youth, and for immigrant youth compared to older immigrants.

\section{Age at Return}

While migration offers young adults the opportunity to acquire education and earn higher incomes abroad, sending countries often worry that many of these migrants will never return. The proportion of migrants who return is very difficult to measure with the existing data available in most countries. However, the few studies which have been able to measure return show that a high proportion of migrants do return. For example, in the U.S. Jasso and Rosenzweig (1982) estimate that up to 50 percent of the migrants who entered the U.S. in 1971 had returned by 1979. Dustmann (2005) summarizes several other studies, which find rates of return of 80 percent in Switzerland and two-thirds in Germany. Migration return rates can be quite high when the country of return is close by. In a study of migrants from Western Mexico, Reyes (1997) estimates that about 50 percent of all immigrants return within two years, and by 10 years, almost 70 percent had returned.

Given that many migrants return, a key question is then at what age do they return? Individuals who return while relatively young will have more of their working lives to spend in their home countries, potentially using skills acquired abroad. In contrast, individuals who return to their home countries only after retirement may have greatest impact through the savings they bring back. Several household surveys ask questions on 
last place of residence 12 months or 5 years ago, making it possible to look at the age of return for recent return migrants.

Figure 2 plots the age distribution of return migration in five countries, showing that migrants tend to return at fairly young ages. The median age of return migration is 24 in Mexico, 28 in South Africa, 30 in Pakistan, 31 in Albania and 34 in the Philippines. This includes the return migration of some individuals who migrated as young children, and does not tell us the duration of time spent abroad. Three of the household surveys also ask when migrants left their home countries, as well as when they returned, allowing calculation of durations of migration, and age of return conditional on leaving as a youth. The median (mean) time abroad for youth migrants from Mexico is 3 years (5 years); from Pakistan 4 years (6 years) and from Albania 7 months (19 months). The median age of return for youth migrating between age 12 and 24 in all three countries is 24 to 25 years. This shows that most youth who ever return, do so while still fairly young, meaning that they have many years of working life in their home countries.

\section{Conclusions}

This paper shows that youth constitute a large share of the migrant flow, and that most return migrants are also relatively young. The rich descriptive detail provided in this paper offers a basis for understanding better the characteristics and experience of these youth migrants - which should be of interest to policymakers in both sending and receiving countries. 
The descriptive analysis in this report suggests several areas which warrant policy attention and further academic study. Firstly, while youth have a high tendency to migrate, youth constitute a much lower share of migrants to developed countries with migration systems that select on skills. Several other countries appear to be considering targeting high-skilled workers more in their migration policies, with the "points-system" announced by the United Kingdom recently one such example. It should be recognized that such systems offer few opportunities to the large number of young people in the world who wish to migrate temporarily, and therefore a challenge for policymakers is how to offer more opportunities.

Secondly, the analysis shows that the large majority of young migrants are either in school or are working. One interesting finding is that there are high shares of migrant youth attending school past age 18 in Argentina and South Africa. This shows the potential for South-South migration to be beneficial in developing human capital. Nevertheless, one concern is that there are also sizeable numbers of older youth who are neither in school or working. Further work needs to explore the reasons for this lack of activity, and help develop policies to better integrate immigrate youth into the labor market. 


\section{Appendix: Sources of Data Used}

Note: Classifications where cell sizes are 30 or less were not used, and are marked s.s. (small sample) in Tables

\section{Data Sources}

Albania: Data on return migration is from the 2005 Albania Living Standards Measurement Survey, a nationally representative survey which includes data on 1419 return migrants.

Argentina: We combine seven waves of the EPH labor force survey, taken between October 1999 and October 2002, in order to achieve a sufficiently large sample of migrants. As this is a rotating panel, we drop subsequent observations on the same individuals in order to sample each migrant only once. This yields a sample of 16,890 born outside of Argentina, of whom 1,247 are aged 12 to 24 and are from developing countries. Of these, 183 came to Argentina within two years of the survey year. The native youth sample are taken from the October 2002 wave of the same survey.

Canada: Data used are from the $2.7 \%$ public use file on individuals from the 2001 Census. This data contains individual records for 154,280 individuals born outside of Canada, of whom 12,386 are aged 12 to 24 and are from developing countries. Of these, 1,944 came to Canada in 1999 or later. The public use data only contains 25 occupation categories, and so Herfindahl indices of occupational concentration are not calculated.

Côte d'Ivoire: Data used are from the May 2002 Enquete Niveau de Vie des Menages (Household Living Standards Survey). This yields a sample of 4,548 individuals born outside of Côte d'Ivoire, of whom 973 are aged 12 to 24. Of these, 662 came to Côte d'Ivoire within five years of the survey date. Data on country of birth is not available, but 
data on ethnicity suggest the vast majority of migrants are from within Africa, and are used to give the major countries of origin.

Mexico: Data for return migration are from the 1997 Encuesta Nacional de la Dinamica Demografica (ENADID), a nationally representative demographic survey with individual records for 175,631 individuals. Data on return migration from the United States is available for 4,917 individuals.

Oman: Customized cross-tabulations were provided by the Minister of National Economy based on the 2003 General Population and Housing Census.

Pakistan: Data on 96 return migrants from international destinations are from the Pakistan Rural Household Survey 2001/02.

The Philippines: Data on return migration are from the 1993 to 2000 waves of the Survey on Overseas Filipinos, providing data on 4548 return migrants.

South Africa: Data used are from the 10\% sample of the 2001 Census, supplied by Statistics South Africa. This data contains individual records for 82,593 individuals born outside of South Africa, of whom 13,527 are aged 12 to 24 and are from developing countries. Of these, 2,892 came to South Africa in 1999 or later - which we define as being a recent migrant. Migrants are defined as being from Developing Countries based on place of birth. The occupational classification consists of 170 3-digit occupation categories. Data were available for 2123 South African return migrants who had returned to South Africa in the five years prior to the Census.

Spain: Data used are from the 5\% sample of the 2001 Census, obtained from the Instituto Nacional de Estadística (INE), http://www.ine.es/prodyser/micro_censopv.htm. This data contains individual records for 107,394 individuals born outside of Spain, of whom 
14,812 are aged 12 to 24 and are from developing countries. Of these, 6,922 came to Spain in 1999 or later. The occupational classification consists of 66 2-digit occupation categories.

United Kingdom: Data are from the 3\% sample of anonymised records (SARS) from the 2001 Census, provided by the Cathie Marsh Centre for Census and Surveys Research (University of Manchester). The dataset contains individual records for 134,800 individuals born outside of the United Kingdom, of whom 13,500 are aged 12 to 24 and from developing countries. Of these, 1442 came to the United Kingdom within the last year. Individuals with a country of birth classified as other in the SARS are not counted as developing country migrants here, since this category includes both developed countries (Australia, New Zealand) and some developing countries (South America). The occupational classication consists of only 22 categories, and so Herfindahl indices of occupational concentration are not calculated.

United States: Data are from the 5\% public use sample of the 2000 Census, obtained through the Integrated Public Use Microdata Series (IPUMS) website (Ruggles et al. 2004). The dataset contains individual records for $1,614,057$ individuals born outside of the United States, of whom 238,132 are aged 12 to 24 and are from developing countries. Of these, 35,057 came to the United States in 1999 or later, defined here as recent migrants. The occupation classification consists of 475 occupation codes. 


\section{References}

Dustmann, Christian (2005) "Why go back? Return motives of migrant workers”, Mimeo.

Holzmann, Robert. 2005. "Demographic alternatives for aging industrial societies: Enhanced immigration, labor force participation, or total fertility rate." Paper presented at the G-20 Workshop on Demographic Challenges and Migration.

Jasso, Guilermina and Mark Rosenzweig (1982) "Estimating the emigration rates of legal immigrants using administrative and survey data: the 1971 cohort of immigrants to the United States”, Demography 19: 279-90.

Lauby, Jennifer, and Oded Stark. 1988. "Individual Migration as a Family Strategy: Young Women in the Philippines." Population Studies 42(3):473-486.

Lee, Everitt S. 1966. "A Theory of Migration." Demography 3(1):47-57.

Lundborg, Per. 1991. "An Interpretation of the Effects of Age on Migration: Nordic Migrants' Choice of Settlement in Sweden." Southern Economic Journal 58(2):392-405.

Massey, Douglas S., Joaquín Arango, Graeme Hugo, Ali Kouaouchi, Adela Pellegrino, and Edward Taylor. 1998. Worlds in Motion: Understanding international migration at the end of the millennium. Oxford: Oxford University Press.

McKenzie, David J. 2003. "How do households cope with aggregate shocks? Evidence from the Mexican Peso crisis." World Development 31(7):1179-1199.

Reyes, Belinda (1997) Dynamics of Immigration: Return Migration to Western Mexico, Public Policy Institute of California.

Ruggles, Steven, Matthew Sobek, Trent Alexander, Catherine A. Fitch, Ronald Goeken, Patricia Kelly Hall, Miriam King, and Chad Ronnander (2004) Integrated Public Use 
Microdata Series: Version 3.0 [Machine-readable database]. Minneapolis, MN: Minnesota Population Center, http://www.ipums.org.

Simon, Julian L. 1986. "Basic Data concerning Immigration into the United States." Annals of the American Academy of Political and Social Science 487:12-56.

Sjaastad, Larry A. 1962. "The Costs and Returns of Human Migration." Journal of Political Economy 70(5):80-93.

Stark, Oded, and David E. Bloom. 1985. "The New Economics of Labor Migration." American Economic Review Papers and Proceedings 75(2):173-178.

Stark, Oded, and David Levhari. 1982. "On Migration and Risk in LDCs." Economic Development and Cultural Change 31(1):191-196.

Todaro, Michael (1969). "A Model of Labor Migration and Urban Unemployment in Less Developed Countries". American Economic Review , 138-148.

Yang, Dean and HwaJung Choi (2005). "Are Remittance Insurance? Evidence from Rainfall Shocks in the Philippines". Department of Economics, University of Michigan, Mimeo.

World Bank (2006) World Development Report 2007: Development and the Next Generation, World Bank: Washington D.C. 
Figure 1: Age Patterns of Migrant Flow Around the World by Gender
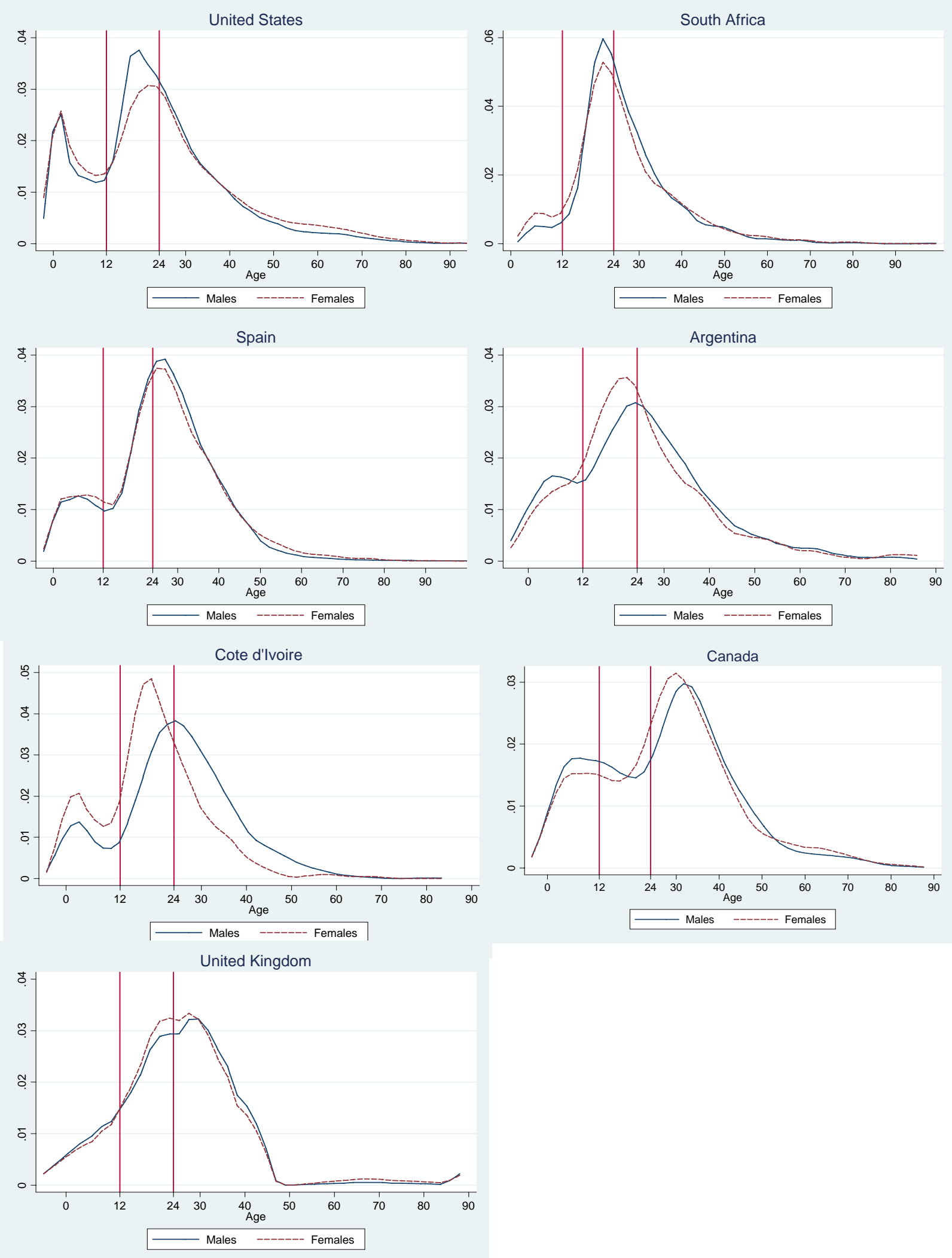

Note: United Kingdom age pattern kinked due to groupings of ages used in SARs. 
Figure 2: Distribution of Age of Return Migration

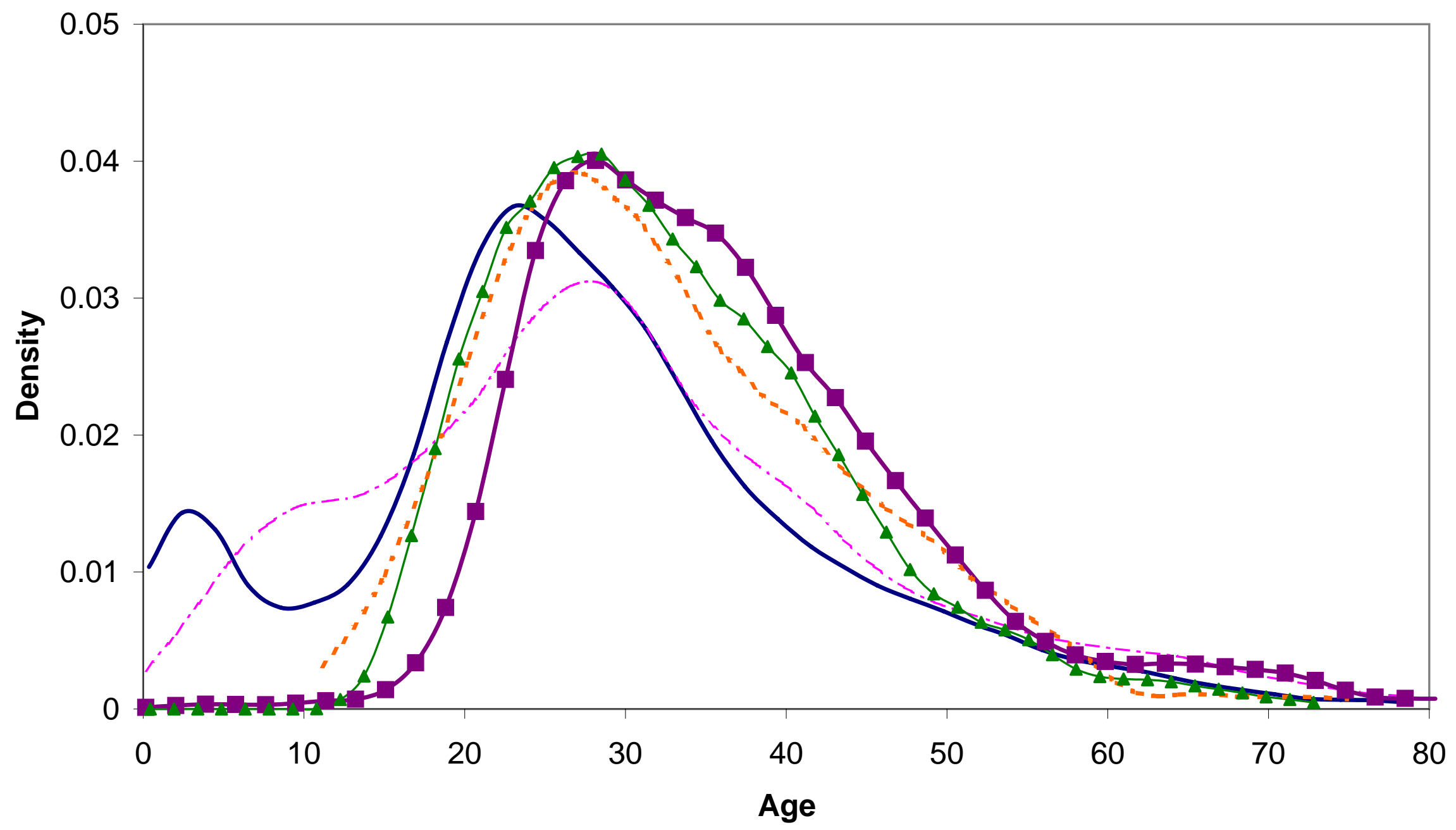

Mexico -.- South Africa $\rightarrow$-Philippines $\longrightarrow$ Albania - - - Pakistan 
Table 1: Share of Immigrants who are youth

\begin{tabular}{llcccc}
\hline \multirow{5}{*}{ Argentina } & \multicolumn{2}{c}{ Share Aged 12 to 24 } & \multicolumn{2}{c}{ Share Aged 12 to 29 } \\
& Males & 0.32 & 0.08 & 0.47 & 0.15 \\
& Females & 0.42 & 0.10 & 0.55 & 0.17 \\
& Overall & 0.38 & 0.09 & 0.52 & 0.16 \\
Cote d'Ivoire & Males & 0.20 & 0.16 & 0.31 & 0.24 \\
& Females & 0.20 & 0.14 & 0.35 & 0.23 \\
& Overall & 0.20 & 0.15 & 0.33 & 0.23 \\
South Africa & Males & 0.34 & 0.52 & 0.17 & 0.30 \\
& Females & 0.50 & 0.63 & 0.27 & 0.43 \\
& Overall & 0.41 & 0.57 & 0.21 & 0.35 \\
Spain & Males & 0.46 & 0.20 & 0.66 & 0.37 \\
& Females & 0.45 & 0.23 & 0.63 & 0.37 \\
& Overall & 0.45 & 0.22 & 0.65 & 0.37 \\
\multirow{5}{*}{ United Kingdom } & Males & 0.27 & 0.47 & 0.20 & 0.36 \\
& Females & 0.27 & 0.46 & 0.20 & 0.34 \\
& Overall & 0.27 & 0.46 & 0.20 & 0.35 \\
United States & Males & 0.31 & 0.15 & 0.52 & 0.24 \\
& Females & 0.35 & 0.14 & 0.56 & 0.25 \\
& Overall & 0.33 & 0.15 & 0.54 & 0.25 \\
& Males & 0.38 & 0.20 & 0.51 & 0.31 \\
& Females & 0.33 & 0.17 & 0.45 & 0.27 \\
& Overall & 0.36 & 0.18 & 0.49 & 0.29 \\
\hline
\end{tabular}

Table 2: Share of Immigrants who are female

\begin{tabular}{lcccc}
\hline & \multicolumn{2}{c}{ Immigrants 12 to 24 } & \multicolumn{2}{c}{ All Immigrants } \\
& Flow & Stock & Flow & Stock \\
\hline Argentina & 0.65 & 0.57 & 0.59 & 0.54 \\
Canada & 0.51 & 0.49 & 0.51 & 0.52 \\
Cote d'Ivoire & 0.52 & 0.54 & 0.42 & 0.42 \\
Oman & n.a. & 0.42 & n.a. & 0.26 \\
South Africa & 0.39 & 0.41 & 0.39 & 0.38 \\
Spain & 0.48 & 0.48 & 0.48 & 0.49 \\
United Kingdom & 0.55 & 0.50 & 0.52 & 0.51 \\
United States & 0.42 & 0.45 & 0.46 & 0.49 \\
\hline
\end{tabular}

Note: Share for Oman is for 10 to 24 year olds. 
Table 3: Proportion of Youth Migrants Living with a Parent by Age

\begin{tabular}{|c|c|c|c|c|c|c|c|c|c|}
\hline & & \multicolumn{4}{|c|}{ Recent Youth Migrants } & \multicolumn{4}{|c|}{ All Youth Migrants } \\
\hline & & 12 to 14 & 15 to 17 & 18 to 24 & All 12 to 24 & 12 to 14 & 15 to 17 & 18 to 24 & All 12 to 24 \\
\hline \multirow[t]{2}{*}{ Argentina } & Males & s.s. & S.S. & 0.26 & 0.37 & 0.88 & 0.85 & 0.60 & 0.68 \\
\hline & Females & S.s. & S.s. & 0.13 & 0.26 & 0.85 & 0.83 & 0.39 & 0.54 \\
\hline \multirow[t]{2}{*}{ Canada } & Males & 0.93 & 0.93 & 0.57 & 0.76 & 0.96 & 0.93 & 0.70 & 0.80 \\
\hline & Females & 0.93 & 0.87 & 0.38 & 0.62 & 0.94 & 0.91 & 0.59 & 0.72 \\
\hline \multirow[t]{2}{*}{ Cote d'Ivoire } & Males & s.s. & 0.33 & 0.09 & 0.15 & 0.58 & 0.44 & 0.19 & 0.27 \\
\hline & Females & 0.45 & 0.18 & 0.06 & 0.12 & 0.48 & 0.26 & 0.09 & 0.16 \\
\hline \multirow[t]{2}{*}{ South Africa } & Males & 0.55 & 0.25 & 0.06 & 0.11 & 0.74 & 0.55 & 0.18 & 0.28 \\
\hline & Females & 0.59 & 0.34 & 0.08 & 0.15 & 0.76 & 0.57 & 0.24 & 0.35 \\
\hline \multirow[t]{2}{*}{ Spain } & Males & 0.79 & 0.70 & 0.19 & 0.32 & 0.79 & 0.73 & 0.28 & 0.41 \\
\hline & Females & 0.81 & 0.66 & 0.17 & 0.32 & 0.80 & 0.70 & 0.25 & 0.40 \\
\hline \multirow[t]{2}{*}{ United Kingdom } & Males & 0.92 & 0.42 & 0.06 & 0.23 & 0.92 & 0.76 & 0.28 & 0.54 \\
\hline & Females & 0.95 & 0.39 & 0.05 & 0.19 & 0.94 & 0.73 & 0.17 & 0.44 \\
\hline \multirow[t]{2}{*}{ United States } & Males & 0.82 & 0.51 & 0.17 & 0.30 & 0.92 & 0.79 & 0.37 & 0.52 \\
\hline & Females & 0.83 & 0.61 & 0.20 & 0.36 & 0.93 & 0.83 & 0.38 & 0.55 \\
\hline
\end{tabular}

Notes:

See data appendix for definition of recent migrant

Data for UK is for groupings 12 to 14,15 to 19 , and 20 to 24 due to SARS age groupings.

Table 4: Proportion of Youth Migrants who are Married by Age

\begin{tabular}{|c|c|c|c|c|c|c|c|c|c|}
\hline & & \multicolumn{4}{|c|}{ Recent Youth Migrants } & \multicolumn{4}{|c|}{ All Youth Migrants } \\
\hline & & 12 to 14 & 15 to 17 & 18 to 24 & All 12 to 24 & 12 to 14 & 15 to 17 & 18 to 24 & All 12 to 24 \\
\hline \multirow[t]{2}{*}{ Argentina } & Males & S.S. & S.S. & 0.17 & 0.12 & 0.00 & 0.00 & 0.09 & 0.06 \\
\hline & Females & s.s. & s.s. & 0.29 & 0.22 & 0.00 & 0.04 & 0.18 & 0.13 \\
\hline \multirow[t]{2}{*}{ Canada } & Males & n.a. & 0.00 & 0.12 & 0.06 & n.a. & 0.01 & 0.05 & 0.03 \\
\hline & Females & n.a. & 0.02 & 0.45 & 0.25 & n.a. & 0.01 & 0.16 & 0.10 \\
\hline \multirow[t]{2}{*}{ Cote d'Ivoire } & Males & s.s. & 0.03 & 0.16 & 0.14 & 0.02 & 0.05 & 0.16 & 0.13 \\
\hline & Females & 0.05 & 0.41 & 0.76 & 0.63 & 0.06 & 0.34 & 0.75 & 0.60 \\
\hline \multirow[t]{2}{*}{ South Africa } & Males & 0.00 & 0.03 & 0.11 & 0.10 & 0.01 & 0.03 & 0.16 & 0.13 \\
\hline & Females & 0.00 & 0.11 & 0.37 & 0.31 & 0.02 & 0.10 & 0.41 & 0.32 \\
\hline \multirow[t]{2}{*}{ Spain } & Males & 0.00 & 0.02 & 0.13 & 0.10 & 0.00 & 0.01 & 0.10 & 0.08 \\
\hline & Females & 0.00 & 0.07 & 0.32 & 0.24 & 0.00 & 0.04 & 0.25 & 0.18 \\
\hline \multirow[t]{2}{*}{ United Kingdom } & Males & 0.00 & 0.02 & 0.06 & 0.05 & 0.00 & 0.01 & 0.11 & 0.06 \\
\hline & Females & 0.00 & 0.05 & 0.15 & 0.11 & 0.00 & 0.05 & 0.26 & 0.16 \\
\hline \multirow[t]{2}{*}{ United States } & Males & n.a. & 0.04 & 0.18 & 0.14 & n.a. & 0.03 & 0.20 & 0.14 \\
\hline & Females & n.a. & 0.10 & 0.40 & 0.29 & n.a. & 0.05 & 0.35 & 0.24 \\
\hline
\end{tabular}

Notes: Marital status is only asked of those 15 and older in the U.S. and Canada

Data for UK is for groupings 12 to 14,15 to 19 , and 20 to 24 due to SARS age groupings. 
Table 5: Proportion of Youth Migrants Attending School by Age

\begin{tabular}{|c|c|c|c|c|c|c|c|c|c|}
\hline & & \multicolumn{4}{|c|}{ Recent Youth Migrants } & \multicolumn{4}{|c|}{ All Youth Migrants } \\
\hline & & 12 to 14 & 15 to 17 & 18 to 24 & All 12 to 24 & 12 to 14 & 15 to 17 & 18 to 24 & All 12 to 24 \\
\hline \multirow[t]{2}{*}{ Argentina } & Males & S.S & S.S & 0.30 & 0.34 & 0.96 & 0.68 & 0.28 & 0.42 \\
\hline & Females & S.S & s.s & 0.14 & 0.27 & 0.93 & 0.73 & 0.30 & 0.46 \\
\hline \multirow[t]{2}{*}{ Canada } & Males & 1.00 & 0.84 & 0.58 & 0.76 & 1.00 & 0.84 & 0.65 & 0.76 \\
\hline & Females & 1.00 & 0.87 & 0.52 & 0.71 & 1.00 & 0.84 & 0.65 & 0.76 \\
\hline \multirow[t]{2}{*}{ Cote d'Ivoire } & Males & s.s. & 0.14 & 0.02 & 0.06 & 0.42 & 0.24 & 0.04 & 0.11 \\
\hline & Females & 0.13 & 0.00 & 0.01 & 0.02 & 0.17 & 0.02 & 0.02 & 0.04 \\
\hline \multirow[t]{2}{*}{ South Africa } & Males & 0.83 & 0.53 & 0.28 & 0.34 & 0.87 & 0.69 & 0.24 & 0.35 \\
\hline & Females & 0.92 & 0.68 & 0.37 & 0.46 & 0.89 & 0.71 & 0.30 & 0.43 \\
\hline \multirow[t]{2}{*}{ Spain } & Males & 0.95 & 0.65 & 0.13 & 0.29 & 0.96 & 0.71 & 0.22 & 0.40 \\
\hline & Females & 0.97 & 0.66 & 0.16 & 0.34 & 0.96 & 0.70 & 0.26 & 0.43 \\
\hline \multirow[t]{2}{*}{ United Kingdom } & Males & 1.00 & 0.76 & 0.58 & 0.66 & 1.00 & 0.80 & 0.46 & 0.65 \\
\hline & Females & 1.00 & 0.69 & 0.48 & 0.57 & 1.00 & 0.78 & 0.39 & 0.59 \\
\hline \multirow[t]{2}{*}{ United States } & Males & 0.90 & 0.56 & 0.22 & 0.36 & 0.97 & 0.83 & 0.30 & 0.49 \\
\hline & Females & 0.92 & 0.71 & 0.27 & 0.44 & 0.97 & 0.89 & 0.37 & 0.57 \\
\hline
\end{tabular}

Notes:

See data appendix for definition of recent migrant

School attendance only asked for those 15 and over in Canada, so presumed at 100\% for those under 15

Data for UK is for groupings 12 to 14,15 to 19 , and 20 to 24 due to SARS age groupings.

Table 6: Proportion of Youth Migrants Working by Age

\begin{tabular}{|c|c|c|c|c|c|c|c|c|c|}
\hline & & \multicolumn{4}{|c|}{ Recent Youth Migrants } & \multicolumn{4}{|c|}{ All Youth Migrants } \\
\hline & & 12 to 14 & 15 to 17 & 18 to 24 & All 12 to 24 & 12 to 14 & 15 to 17 & 18 to 24 & All 12 to 24 \\
\hline \multirow[t]{2}{*}{ Argentina } & Males & S.S & S.S & 0.43 & 0.43 & 0.02 & 0.20 & 0.54 & 0.42 \\
\hline & Females & S.S & S.S & 0.49 & 0.39 & 0.01 & 0.09 & 0.39 & 0.28 \\
\hline \multirow[t]{2}{*}{ Canada } & Males & n.a. & 0.18 & 0.55 & 0.31 & n.a. & 0.22 & 0.55 & 0.37 \\
\hline & Females & n.a. & 0.16 & 0.43 & 0.27 & n.a. & 0.22 & 0.53 & 0.36 \\
\hline \multirow[t]{2}{*}{ Cote d'Ivoire } & Males & s.s. & 0.46 & 0.87 & 0.77 & 0.30 & 0.45 & 0.80 & 0.70 \\
\hline & Females & 0.45 & 0.39 & 0.38 & 0.39 & 0.38 & 0.34 & 0.41 & 0.39 \\
\hline \multirow[t]{2}{*}{ South Africa } & Males & 0.08 & 0.22 & 0.46 & 0.42 & 0.04 & 0.12 & 0.49 & 0.41 \\
\hline & Females & 0.02 & 0.06 & 0.18 & 0.15 & 0.02 & 0.05 & 0.23 & 0.18 \\
\hline \multirow[t]{2}{*}{ Spain } & Males & 0.01 & 0.19 & 0.68 & 0.54 & 0.00 & 0.18 & 0.63 & 0.48 \\
\hline & Females & 0.01 & 0.13 & 0.52 & 0.40 & 0.01 & 0.12 & 0.49 & 0.36 \\
\hline \multirow[t]{2}{*}{ United Kingdom } & Males & n.a. & 0.22 & 0.42 & 0.33 & n.a. & 0.22 & 0.49 & 0.33 \\
\hline & Females & n.a. & 0.26 & 0.42 & 0.35 & n.a. & 0.24 & 0.43 & 0.32 \\
\hline \multirow[t]{2}{*}{ United States } & Males & n.a. & 0.40 & 0.65 & 0.60 & n.a. & 0.27 & 0.65 & 0.59 \\
\hline & Females & n.a. & 0.19 & 0.37 & 0.34 & n.a. & 0.20 & 0.46 & 0.42 \\
\hline
\end{tabular}

Notes:

See data appendix for definition of recent migrant

Work status only asked for those 15 and over in the United States and Canada, and those 16 and over in the UK

Data for UK is for groupings 12 to 14,15 to 19 , and 20 to 24 due to SARS age groupings. 
Table 7: Proportion of Youth Migrants Not Working and Not Attending School by Age

\begin{tabular}{|c|c|c|c|c|c|c|c|c|c|}
\hline & & \multicolumn{4}{|c|}{ Recent Youth Migrants } & \multicolumn{4}{|c|}{ All Youth Migrants } \\
\hline & & 12 to 14 & 15 to 17 & 18 to 24 & All 12 to 24 & 12 to 14 & 15 to 17 & 18 to 24 & All 12 to 24 \\
\hline \multirow[t]{2}{*}{ Argentina } & Males & S.S & S.S & 0.26 & 0.24 & 0.02 & 0.16 & 0.24 & 0.20 \\
\hline & Females & S.S & S.S & 0.41 & 0.37 & 0.05 & 0.19 & 0.37 & 0.30 \\
\hline \multirow[t]{2}{*}{ Canada } & Males & n.a. & 0.12 & 0.13 & 0.09 & n.a. & 0.10 & 0.09 & 0.08 \\
\hline & Females & n.a. & 0.11 & 0.23 & 0.15 & n.a. & 0.11 & 0.12 & 0.10 \\
\hline \multirow[t]{2}{*}{ Cote d'Ivoire } & Males & S.S. & 0.46 & 0.11 & 0.17 & 0.32 & 0.35 & 0.16 & 0.20 \\
\hline & Females & 0.42 & 0.61 & 0.60 & 0.59 & 0.44 & 0.64 & 0.57 & 0.57 \\
\hline \multirow[t]{2}{*}{ South Africa } & Males & 0.10 & 0.27 & 0.29 & 0.27 & 0.10 & 0.20 & 0.31 & 0.27 \\
\hline & Females & 0.08 & 0.27 & 0.47 & 0.41 & 0.10 & 0.25 & 0.50 & 0.42 \\
\hline \multirow[t]{2}{*}{ Spain } & Males & 0.04 & 0.18 & 0.23 & 0.20 & 0.03 & 0.13 & 0.20 & 0.17 \\
\hline & Females & 0.03 & 0.23 & 0.36 & 0.30 & 0.03 & 0.19 & 0.31 & 0.25 \\
\hline \multirow[t]{2}{*}{ United Kingdom } & Males & n.a. & 0.09 & 0.08 & 0.07 & n.a. & 0.08 & 0.14 & 0.10 \\
\hline & Females & n.a. & 0.11 & 0.18 & 0.15 & n.a. & 0.10 & 0.27 & 0.18 \\
\hline \multirow[t]{2}{*}{ United States } & Males & n.a. & 0.19 & 0.23 & 0.22 & n.a. & 0.09 & 0.20 & 0.18 \\
\hline & Females & n.a. & 0.24 & 0.46 & 0.42 & n.a. & 0.10 & 0.34 & 0.30 \\
\hline
\end{tabular}

Notes:

See data appendix for definition of recent migrant

Work status only asked for those 15 and over in the United States and Canada, and 16 and over in the UK.

Data for UK is for groupings 12 to 14,15 to 19 , and 20 to 24 due to SARS age groupings. 
Table 8: Top 5 Occupations for 18 to 24 Year Old Migrants

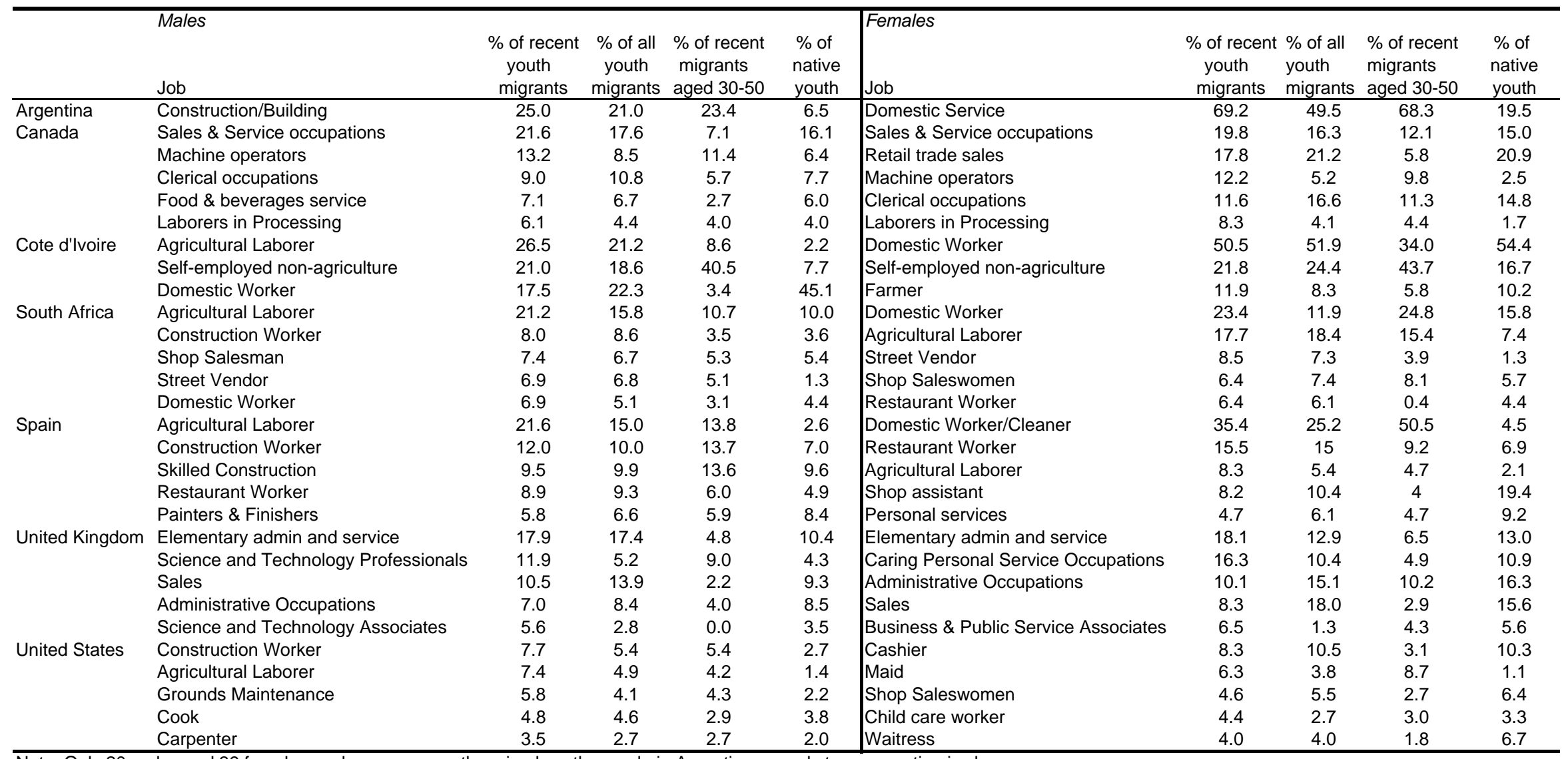

Note: Only 20 males and 39 females work among recently arrived youth sample in Argentina, so only top occupation is shown.

Due to small sample sizes, only top three occupations shown for Cote d'Ivoire.

Notes:

Percentages are Conditional on Working; Youth is defined as 18 to 24 here. 
Table 9: Herfindahl Indices of Occupational Concentration

\begin{tabular}{llccrl}
\hline & & $\begin{array}{l}\text { Recent } \\
\text { Youth } \\
\text { Migrants }\end{array}$ & $\begin{array}{l}\text { All } \\
\text { Youth } \\
\text { Migrants }\end{array}$ & $\begin{array}{l}\text { Recent } \\
\text { Migrants } \\
30 \text { to 50 }\end{array}$ & $\begin{array}{l}\text { Native } \\
\text { Youth }\end{array}$ \\
\hline South Africa & Males & 0.075 & 0.054 & 0.032 & 0.036 \\
& Females & 0.095 & 0.063 & 0.069 & 0.056 \\
Spain & Males & 0.091 & 0.066 & 0.072 & 0.043 \\
& Females & 0.168 & 0.110 & 0.272 & 0.069 \\
United States & Males & 0.027 & 0.018 & 0.016 & 0.017 \\
& Females & 0.026 & 0.026 & 0.020 & 0.034 \\
\hline
\end{tabular}

Notes: Indices are calculated for workers within each group.

Canada and the United Kingdom had too few occupational categories. 
Appendix 1: Main Sources of Developing Country Youth Migrants by Destination Country

\begin{tabular}{|c|c|c|c|c|}
\hline Destination & $\begin{array}{l}\text { FLOW } \\
\text { Main Origin Countries }\end{array}$ & $\begin{array}{l}\% \text { of all developing country } \\
\text { migrants to destination }\end{array}$ & $\begin{array}{l}\text { STOCK } \\
\text { Main Origin Countries }\end{array}$ & $\begin{array}{l}\% \text { of all developing country } \\
\text { migrants to destination }\end{array}$ \\
\hline \multirow{6}{*}{ Argentina } & Paraguay & 30.1 & Chile & 37.6 \\
\hline & Peru & 24.1 & Bolivia & 19 \\
\hline & Bolivia & 17.1 & Paraguay & 18.1 \\
\hline & Chile & 11.6 & |Peru & 9.8 \\
\hline & Brazil & 5.5 & Uruguay & 5.9 \\
\hline & Share from top 5 & 88.4 & Share from top 5 & 90.4 \\
\hline \multirow[t]{6}{*}{ Canada } & India & 15.5 & Central America, South America, Caribbean & 20.8 \\
\hline & West Central Asia and the Middle East & 14.5 & West Central Asia and the Middle East & 14.2 \\
\hline & Central America, South America, Caribbean & 11.7 & Other Eastern and South-East Asia & 13.8 \\
\hline & China & 11.3 & India & 8.2 \\
\hline & Other Eastern and South-East Asia & 9.8 & China & 8.0 \\
\hline & Share from top 5 & 62.8 & Share from top 5 & 64.9 \\
\hline \multirow[t]{4}{*}{ Cote d'Ivoire } & Burkina Faso & 41.7 & Burkina Faso & 41.4 \\
\hline & Other Africa & 30.7 & Other Africa & 31.5 \\
\hline & Mali & 13.9 & Mali & 13.9 \\
\hline & Ghana & 6.3 & Ghana & 5.9 \\
\hline \multirow[t]{6}{*}{ Spain } & Ecuador & 28.5 & Morocco & 21.4 \\
\hline & Morocco & 16.9 & Ecuador & 19.8 \\
\hline & Colombia & 15.7 & Colombia & 12.6 \\
\hline & Romania & 6.5 & Argentina & 5.7 \\
\hline & Argentina & 4.0 & Venezuela & 5.3 \\
\hline & Share from top 5 & 71.6 & Share from top 5 & 64.8 \\
\hline \multirow[t]{6}{*}{ South Africa } & Mozambique & 28.0 & Mozambique & 39.5 \\
\hline & Lesotho & 18.1 & Zimbabwe & 15.3 \\
\hline & Zimbabwe & 17.7 & Lesotho & 13.3 \\
\hline & Botswana & 8.4 & Namibia & 6.5 \\
\hline & Swaziland & 4.1 & Swaziland & 4.0 \\
\hline & Share from top 5 & 76.3 & Share from top 5 & 78.6 \\
\hline \multirow[t]{5}{*}{ United Kingdom } & Rest of Asia & 36.4 & Africa & 30.1 \\
\hline & Africa & 28.7 & Rest of Asia & 29.8 \\
\hline & Eastern Europe & 15.1 & Pakistan and Bangladesh & 19.1 \\
\hline & India & 9.3 & Eastern Europe & 10.6 \\
\hline & Pakistan and Bangladesh & 7.6 & India & 6.6 \\
\hline \multirow[t]{6}{*}{ United States } & Mexico & 50.4 & Mexico & 44.4 \\
\hline & India & 4.6 & Philippines & 3.9 \\
\hline & El Salvador & 3.3 & El Salvador & 3.4 \\
\hline & Guatemala & 2.6 & Vietnam & 3.0 \\
\hline & Colombia & 2.4 & India & 2.7 \\
\hline & Share from top 5 & 63.3 & Share from top 5 & 57.4 \\
\hline
\end{tabular}

Ne: Cote d'Ivoire numbers based on ethnicity of migrants.

United Kingdom SARs does not provide detailed countries of birth, only regions (except India, Pakistan and Bangladesh). 